\title{
DAS ERÍNIAS ÀS EUMÊNIDES: COMO AS CADELAS VINGADORAS AINDA LADRAM UM PASSADO QUE NÃO PASSA
}

\author{
JoÃo LUIZ Rocha do NASCIMENTO ${ }^{1}$
}

\begin{abstract}
Resumo: Aos gregos, com as tragédias, se atribui a iniciativa de desligar o passado e permitir a marcha do tempo para a frente. Literariamente, Eumênides, que compõe a trilogia Oresteia, de Ésquilo, representa a invenção da justiça e do próprio direito: institucionalizou-se pela primeira vez um tribunal para julgar crimes de sangue com base num discurso racional, pondo fim ao sistema vindicativo conhecido como a maldição dos Atridas. Seria correto afirmar que o longínquo julgamento de Orestes ainda é representativo do fim do ciclo de vingança ou os sistemas contemporâneos de direito continuam refletindo aqueles primitivos sistemas, como se as três gotas de sangue de Urano, que deram origem às Erínias, ainda tingissem a terra impedindo que o passado passe? O objetivo deste artigo, sem deixar de reconhecer a contribuição dos helenos, é demonstrar que, no plano da realidade, a conversão das Erínias em Eumênides não completou seu ciclo: há um passado que não se desliga e as memórias longas das deusas vingadoras ainda clamam por vingança, interditada, por certo, com o julgamento de Orestes, mas difícil é negar que o Estado, ao punir, numa dada perspectiva, não continue a reproduzir sentimentos e práticas de vingança, a recordar a maldição dos Atridas.
\end{abstract}

Palavras-Chave: tragédia; vingança; justiça privada; justiça pública; passagem incompleta.

\section{PRÓlOGO}

Crimes de sangue já existiam antes mesmo do homem rústico produzir seu primeiro artefato, e não há quem, seriamente, alimente a

1 Mestre e doutorando em Direito Público pela Universidade do Vale do Rio dos Sinos (UNISINOS). Especialista em Direito Constitucional pela Universidade Federal do Piauí (UFPI) e em Direito Processual pela Universidade Federal de Santa Catarina (UFSC). Professor Assistente do Curso de Direito da Universidade Estadual do Piauí (UESPI). Professor da Pós-Graduação da Estácio de Sá, no Centro de Ensino Unificado de Teresina (CEUT) e do Instituto de Ensinos Empresariais (IEMP/PI). Membro do Projeto de pesquisa Hermenêutica e Teoria da Decisão (UNISINOS). São Leopoldo, RS, Brasil. CV Lattes: http://lattes.cnpq.br/3226175927169455. E-mail: jlrnascimento@gmail.com. 
expectativa de que um dia deixarão de existir. É na mitologia grega que encontramos uma das explicações acerca do que está por trás dos crimes envolvendo membros do mesmo grupo familiar, no que ficou conhecido, e chegou até nossos dias, como a maldição dos Atridas, a história de um ciclo de vingança que se sucede, geração após geração, como forma de se fazer justiça. A tragédia dos Atridas é contada por Ésquilo, dramaturgo grego do século V a. C, em Oresteia, composta por três peças: Agamenon, Coéforas e Eumênides, com destaque para a última, por se tratar da narrativa que representa o fim do sistema vingativo de realização de justiça, ao se instituir, sobre a presidência de Palas Atena, a deusa grega, o primeiro tribunal da história que, ao julgar Orestes pelo assassinato de Clitemnestra, sua mãe, repele o desejo de vingança e lança mão de critérios racionais para punir os crimes de sangue.

Dentre outros legados, além das tragédias, atribui-se aos gregos a iniciativa de desligar o passado e permitir a marcha do tempo para a frente. Em Eumênides, temos literariamente representada a invenção da justiça e, em certa medida, do próprio direito: institucionalizou-se pela primeira vez um tribunal para julgar crimes de sangue com base num discurso público, pondo fim ao sistema vindicativo de realização de justiça conhecido como a maldição dos Atridas.

Passados mais de dois mil anos, seria correto dizer que o julgamento de Orestes é, de fato, representativo do fim do ciclo de vingança como forma de justiça ou será que os sistemas contemporâneos de direito, com seus processos civilizados de punição, ainda refletem os primitivos sistemas vingativos, numa palavra: as três gotas de sangue - as mães fundadoras de Urano derramadas que deram origem às Erínias, as deusas vingadoras, ainda tingem a terra e, por conta disso, o passado não passa?

Eis o objetivo deste artigo: demonstrar, sem menosprezar a grande contribuição dos helenos, que, no plano da realidade, a conversão das Erínias em Eumênides não completou o ciclo planejado: há um passado que não se desliga, como se as longas memórias das deusas vingadoras ainda percorressem os corredores das almas das vítimas e familiares, clamando por vingança, interditada, por certo, a partir da imagem do julgamento de Orestes, pois é impossível negar que o Estado, com o direito 
de punir, numa dada perspectiva, não continue a reproduzir sentimentos e práticas de vingança, a recordar a maldição dos Atridas.

No primeiro ato deste estudo, dividido em duas partes, a tragédia grega será revisitada, oportunidade em que, de início, trataremos do legado grego e da sua contribuição à formação da cultura ocidental para, em seguida, fazer o resgate da história da maldição dos Atridas, quando se evidenciará que, através das tragédias, os gregos inventaram o direito e de como uma delas, a Oresteia, de Ésquilo, simbolicamente, representa a invenção da justiça.

No segundo ato, trataremos de descrever o julgamento de Orestes, em Eumênides, terceira peça da trilogia, atribuindo-lhe o estatuto de marco zero da institucionalização da justiça, por oferecer uma concepção de justiça até então sem precedentes na história, com destaque para o seu significado simbólico: o fim da vingança como sinônimo de realização de justiça, passagem que também marca a transformação - ainda que incompleta das Erínias, até então deusas vingadoras, em Eumênides, as deusas da benevolência e do perdão, que assumem uma nova função na polis, numa demonstração da superação da justiça privada (a vingança) pela justiça pública.

No terceiro ato e último ato, em linhas gerais, o tema é a dificuldade de desligar o passado, à medida que os primitivos sistemas vingativos ainda provocam ressonâncias nos modernos sistemas de direito e de administração de justiça.

Com efeito, na primeira parte, demonstraremos como, passados mais de dois séculos, ainda podemos encontrar vestígios de vingança nas ordens jurídicas modernas, especialmente no direito penal, como se, simbolicamente, ainda representassem a presença das cadelas vingadoras que insistem em ladrar um passado que não passa Em outras palavras: a vingança, pelo menos no plano do desejo, nunca foi extinta, ao reverso, pode-se até mesmo dizer que, de forma indireta, é reverberada pelo Estado quando este lança mão do direito público de punir, o que fica claro na segunda parte do terceiro ato, onde, pontualmente, serão evocadas algumas passagens de sistemas jurídicos penais como reprodutoras da vindita, numa prova de que o passado quase nunca se desliga, seguindo-se, no final, uma síntese com as principais conclusões. 


\section{PRIMEIRO ATO: A TRAGÉDIA REVISITADA:}

\section{Cena I: os gregos e a invenção do direito}

No princípio era o verbo, e o seu nome era vingança. Depois, das trevas se fez a luz, que iluminou o Areópago grego.

Já se disse - e é verdade - que aqui deste lado ocidental, além de cristãos, todos somos um pouco gregos. Quando o assunto é direito, fala-se muito de uma tradição romano-canônica, origem remota de um direito quase asséptico, mas com um profundo déficit antropológico. Quase que se esquece, todavia, que foram os gregos que nos legaram a ideia de razão, de justiça, de democracia ${ }^{3}$, dentre outros valores universais.

Além da filosofia, da política, da democracia e do lúdico - no qual se incluem produções em todas as esferas artísticas -, o que mais transmitiram os gregos? O direito e sua invenção, certamente. Na literatura grega ressurge o mito dos Atridas e, com ele, a concepção do primeiro tribunal e do primeiro julgamento que, movido por critérios racionais, pôs fim ao sistema vingativo, o mais antigo modo de se fazer justiça. A origem das discussões entre direito e moral é apenas um exemplo, dentre tantos, origem no mais das vezes encoberta pela nossa vinculação à tradição romano-canônica. Epopeias e tragédias estarão sempre presentes no imaginário das pessoas e são objetos de reflexão para se pensar o direito, a filosofia e a psicanálise, registre-se. Enfim, que a gênese e as bases para as questões relacionadas com interpretação e aplicação do direito deitam suas raízes na península grega, é algo que parece fora de dúvida.

As lições gregas ainda hoje produzem ressonâncias e nos foram entregues de uma forma privilegiada, com o lúdico. Se Shakespeare, como costuma dizer Streck (2015, p. 231-232), em peças como Medida por medida e $O$ mercador de Veneza, antecipa questões que serão discutidas dois séculos depois, tal contribuição, em certa medida, é mais um ponto, vértice ou não, na curva de uma parábola cuja base está em Antígona, Oresteia e Medeia.

\footnotetext{
O presente artigo adota, deliberadamente, a estrutura das peças teatrais.

3 Democracia é o solo fértil do direito, sem ela não há direito possível, como nos regimes totalitários.
} 
Como defende Neves (2015, p. 260), a obra dos três grandes dramaturgos gregos ${ }^{4}$ revela a conquista da civilização, um desenvolvimento extraordinário que resultou na incorporação de valores como a democracia, a análise de culpa, o julgamento com oportunidade de defesa, a busca pela justiça. E acrescenta:

Os gregos nos deram os cromossomos da civilização ocidental. Nós, contemporâneos, recebemos esse legado extraordinário, alicerce na construção do ordenamento jurídico. Prometeu acorrentado é uma franca denúncia à tirania. Na Oresteia, firma-se a necessidade de ampla defesa. Antígona, por sua vez, representa a luta pelos ideais, pela justiça, em hino à legítima rebeldia. [...] Todos esses valores foram incorporados à nossa cultura por meio dessas peças de teatro. A partir daí, construiu-se uma teoria do direito, estabelecendo-se as bases para um ordenamento jurídico. Esses dramaturgos, por consequência, inventaram o direito (Neves, 2015, p. 260-261).

Claro que, como tudo que é onipresente, sempre pesará sobre nossa consciência fortes ligações com a tradição romanística, mas, como pontua Neves (2015, p. 261), foram os gregos do século V a. C os responsáveis por estabelecer as bases para o direito tal como o conhecemos hoje, "assentadas sobre grandes valores, tais como o respeito à dignidade humana, o direito de defesa, a apreciação da responsabilidade e o julgamento racional”.

Que a cultura ocidental, sobretudo no que se refere à arte, seja tributária do gênio grego ninguém duvida, e a Ilustração talvez seja o exemplo mais emblemático. É bem verdade que, no direito, muito menos do que na filosofia5, essa influência não tem tanta visibilidade, encoberta que foi pelo histórico domínio de uma tradição romanística de viés essencialmente privado ${ }^{6}$, muito provavelmente imposto mais pelo fio da espada do que pelo poder da razão.

De toda sorte, não há como negar que o fenômeno do reencontro do direito com a moral, e com o seu sentido antropológico, o princípio democrático, a constitucionalização dos direitos sociais, a eficácia horizontal dos direitos fundamentais e a ampliação do espaço do direito público - conquista inicial da revolução francesa, sobretudo -, com a

4 Ésquilo, Eurípedes e Sófocles.

5 Neves (2015, p. 63), citando B. Williams, afirma que "o legado da Grécia à filosofia ocidental é a filosofia ocidental”.

6 Como se sabe, o antigo direito romano, fonte primária da tradição civil law, não conheceu o direito público, que surgiu somente a partir do século XVIII, com as revoluções liberais. 
consequente redução do direito privado ocorridos nos últimos 60 anos, têm na cultura grega sua inspiração de fundo.

De fato, não foram os gregos que legaram ao mundo a ideia de um conjunto de leis reunidas num livro considerado tão sagrado que a orientação era a de ser guardado ao lado da Bíblia e que tem no Código de Napoleão o seu exemplo mais acabado. Isso não significa dizer, entretanto, que os helenos não tenham sua parcela de participação no surgimento do direito, ainda que de forma indireta. No princípio, o direito nasce da religião, as leis têm origem divina, assim acreditavam as antigas civilizações, mas serão os gregos os grandes responsáveis pela ruptura desse paradigma.

Comparato (2013, p. 21) anota que no século V a. C., na Ásia, como na Grécia, durante o chamado "século de Péricles", nasce a filosofia e com ela, pela primeira vez na História se dá a substituição do saber mitológico da tradição pela razão, quando o indivíduo atreve-se a fazer uma crítica racional da realidade e é nesse mesmo século que, em Atenas, surgem a um só tempo a tragédia e a democracia, numa sincronia que não foi fruto do acaso.

Na mesma trilha de raciocínio, Neves (2015) afirma que os gregos do século $\mathrm{V}$ a. $\mathrm{C}$ foram os responsáveis por estabelecer as bases para o direito na forma como se conhece hoje, assentado sobre grandes valores como o respeito à dignidade da pessoa humana, o direito de defesa e o julgamento racional transmitidos mediante o manejo de uma ferramenta que não conheceu rival no seu tempo: a cultura, que tem na dramaturgia o exemplo mais privilegiado, pois ela é a fonte de inspiração para as primeiras lições de direito.

Neves (2015, p. 241-243) defende também que,

nas obras dos dramaturgos gregos, conseguimos assistir como se cruzou essa ponte, deixando para trás os aspectos religiosos, para entregar ao homem a legitimidade de construir os ordenamentos jurídicos. A caminhada segue até que Aristóteles reconhece: ‘A lei é a razão'. A filosofia, assim, mata os deuses. [...] A desmitificação é evidente. Os deuses morrem, e os homens ganham força.

E continua sua reflexão, assinalando que

Com as tragédias, todas escritas entre os anos 500 e 405 a. $\mathrm{C}$, em certo ponto, com as comédias, consegue-se identificar a invenção do direito como instituição, guardião dos valores como a justiça e o respeito ao ser humano. Nesse momento 
histórico, o direito separa-se da religião e ganha autonomia, com esteio na racionalidade. $\mathrm{O}$ direito encontra-se impregnado nessas obras, que representam, no conceito mais puro possível, o que se pode denominar 'cultura' e, como tal, moldam a civilização. Os dramaturgos gregos tiveram o papel de estabelecer padrões, até hoje válidos. Dante leu os gregos, Shakespeare leu os gregos, assim como Milton e Joyce. Harold Bloom, o famoso crítico literário e pensador, afirma: "nosso único modo de pensar vem dos antigos gregos". [...] Podemos dizer, assim, que foi por meio dessas peças que se inventou o direito na forma como conhecemos hoje (Neves, 2015, p. 31-32).

Por sua vez, utilizando-se do exemplo de Antígona, Pinto (2008, p. 83) lembra que não causa nenhuma surpresa o fato de que esteja no centro da trama a decisão a ser tomada sobre o ser ou não ser justo, sendo o exemplo mais célebre desse dilema o diálogo sobre justiça protagonizado por Antígona e Creonte e que envolve a polêmica acerca do sepultamento de Polinices. Enquanto Antígona sustenta que o que está em jogo é o direito a um sepultamento conforme as leis atemporais, não-escritas e intangíveis ditadas pelos deuses e não pelos homens, Creonte, redarguindo, afirma que, como Polinices atentou contra a cidade, não pode ser sepultado conforme o ritual praticado na pólis, para, em seguida, ouvir a tréplica de Antígona, na qual lembra que mesmo o poder soberano encontra seus limites.

No mesmo sentido, Streck (2015, p. 229-230), quando diz que desde a Antígona de Sófocles se discute lei e direito, direito e ética, direito e moral e destaca que foi nessa tragédia que Antígona, personagem principal que dá o nome à obra, foi capaz de desafiar uma lei que considerava iníqua com o objetivo de garantir a sepultura de Polinices, seu irmão, morto numa disputa fratricida pelo poder na cidade de Tebas. Para além disso, Streck lembra que com os gregos institucionalizou-se o primeiro tribunal da história com a função de julgar um ato criminoso e estabelecer a punição adequada mediante um devido processo legal, pondo fim à vingança do tipo "olho por olho, dente por dente", que até então imperava, porquanto "na Oresteia, celebra-se o elemento civilizador com a instituição, pela mão da deusa Palas Atena, de um corpo de jurados para julgar os crimes de sangue" (Streck, 2015, p. 230).

Certamente que os crimes de sangue não se extinguiram, mas isso não retira dos gregos, com suas tragédias, a invenção do modo racional de julgálos. Essa a lição transmitida ao mundo contemporâneo. 


\section{Cena II: a maldição dos Atridas 7}

De acordo com Brandão (1986,) tudo começou com a hamartía ${ }^{8}$ de um rei chamado Tântalo, filho de Zeus e Plutô, que, desejando a imortalidade, sacrificou o próprio filho Pélops e, num jantar, o ofereceu aos deuses e é amaldiçoado. Pélops ressuscita, casa-se com Hipodâmia, não sem antes matar Enômono, seu pai e o rei de Élida, que não queria o casamento com receio de ser confirmada a profecia de que seria morto pelo genro. Da união de Péolops e Hipodâmia, nasceram os gêmeos Atreu e Tiestes. Influenciados pela mãe, temerosa de que os filhos perdessem o trono para o enteado, eles matam o meio-irmão Crisipo. Pelóps culpa Hipodâmia pelo infortúnio, que se mata em seguida. Atreu e Tiestes disputam o trono de Micenas e odeiam-se, ódio que é alimentado por traições, adultério, incesto, canibalismo e morte. Aérope, a mulher de Atreu, torna-se amante de Tiestes. Traído, Atreu, para se vingar, mata os filhos de Tiestes e em seguida o convida para um banquete, "num festim de fingida reconciliação" (Berveiller, 1935, p. 112) em que serve como prato principal os dois filhos do irmão, que se refestela sem saber que devora a própria carne. Ao tomar conhecimento da crueldade, Tiestes jura vingança e é banido. No exílio, em Sicionee, consulta um oráculo e dele recebe uma revelação: se possuísse Pelópia, sua própria filha, e dessa relação nascesse um filho, este mataria Atreu. Disfarçado, Tiestes estupra a filha e desse ato nasce Egisto, que é abandonado pela mãe. Atreu, já viúvo, ignorando o ocorrido, apaixona-se por Pelópia, manda resgatar Egisto e o cria como se fora filho seu. Tempos depois, sabendo que Tiestes ainda era vivo, Atreu ordena a Egisto que o mate. Antes da consumação do ato, Tiestes se identifica como o verdadeiro pai e dá-lhe uma contraordem, que é executada: matar Atreu. Pelópia, ao saber quem era o verdadeiro pai de seu filho, suicida-se.

Atreu teve dois filhos: Agamenon e Menelau. Este era rei de Esparta e casa-se com Helena; enquanto Agamenon apaixona-se pela irmã de Helena, Clitemnestra, que já era casada, só lhe restando uma alternativa: matar o marido e um filho recém-nascido do casal. Viúva e a contragosto, Clitemnestra casa-se com Agamenon, e dessa união nascem quatro filhos:

\footnotetext{
7 Filhos de Atreu.

8 Do grego, tem o significado de erro, falta.
} 
Ifigênia, Crisótemis, Electra e Orestes. Durante a guerra de Troia, Egisto se torna amante de Clitemnestra e, quando Agamenon retorna, é morto pela própria esposa - que nunca o perdoara por ter sacrificado Ifigênia, a filha primogênita, antes de partir para a guerra de Troia. Após a morte de Agamenon, Orestes foge para escapar da morte. Muitos anos depois, adulto, Orestes retorna e, juntamente com Electra, planeja e mata a própria mãe e o amante. Orestes, que é inocente porque vinga o pai e ao mesmo tempo culpado porque mata a mãe, vai a julgamento - e é absolvido com o voto de desempate de deusa Atena, que preside o Conselho de Sentença - e pela primeira vez o ciclo de morte é interrompido e a vingança deixa de ser conceito de justiça.

\title{
SEGUNDO ATO: A INSTITUCIONALIZAÇÃO DA JUSTIÇA E O FIM DA VINGANÇA
}

\section{Cena I: o rito de passagem: das Erínias às Eumênides}

Como se sabe, era assim na Grécia antiga: vingança ${ }^{9}$ durante muito tempo foi sinônimo de justiça. Conforme registra Neves (2015):

\begin{abstract}
Em todas as peças que compõem a Trilogia Oresteia, identifica-se o elemento da hereditariedade da culpa, isto é, as personagens respondem por atos nefastos cometidos por seus antepassados, embora eles próprios agravem essa culpa, por também tomarem decisões equivocadas. [...]. Guénos, grupo composto pelos parentes com vínculo de sangue, é um tema relevante na sociedade grega e comum nas tragédias. Se uma pessoa comete um crime contra outra, o guénos do lesado deve vingar-se. Se uma pessoa age contra alguém de seu próprio grupo familiar, cabe a todo o guénos promover a vingança. [...] Assim, o mal contra alguém de seu próprio sangue trazia para o autor do ato e para todo o seu guénos, a repreensão divina, de forma que seus descendentes ficavam marcados. Os gregos acreditavam que quem atacasse seu próprio sangue atraia a ira dos deuses (Neves, 2015, p. 133).
\end{abstract}

O fim do significado de vingança como sinônimo de justiça só vai ocorrer na terceira e última peça da trilogia (Eumênides), que imporá um ponto final ao sistema vindicativo ao submeter a julgamento, de terceiros, o crime praticado por Orestes. De fato, em Agamenon, primeira peça, Ésquilo

9 Neves (2015, p. 143) registra que "a palavra grega para vingança diképhoros, é a tradução literal para 'aquele que traz justiça'. Assim, a vingança, inicialmente, estava intimamente relacionada à justiça”. 
vai tratar da morte do líder grego na vitória da guerra contra Troia, assassinado pela própria mulher, Clitemnestra, com a cumplicidade de Egisto, seu amante. Trata-se de uma narrativa sobre vingança que assume o significado de justiça.

Para que se a compreenda, necessário lembrar parte da história narrada por Homero, no poema Ilíada: os deuses submetem Agamenon a uma duríssima prova. Não havia vento suficiente que permitisse à esquadra grega lançar-se ao mar em direção à Troia, e a condição imposta pela deusa Ártemis para que os ventos soprassem era o sacrifício de Ifigênia, a filha primogênita de Agamenon. Entre preservar a família e tomar uma decisão de Estado, Agamenon optou por esta última e imolou a filha, razão pela qual Clitemnestra jamais o perdoará, eis o principal motivo de sua vingança, influenciada também por Egisto, seu amante, que também havia jurado vingança pela morte de seus irmãos e pela humilhação sofrida por seu pai, todos vítimas de Atreu, pai de Agamenon. Para eles, tudo era uma questão de justiça e, na primeira chance, Clitemnestra, com a ajuda de Egisto, mata o próprio marido durante o banho e assume o poder na cidade de Argos.

Coéforas, a segunda peça, tem também na vingança o tema principal. Sobre o túmulo de Agamenon, Orestes e Electra já falavam em justiça, que somente poderia ser obtida com a vingança pela morte do pai e a restituição do trono usurpado pela mãe e Egisto. É quando decidem vingá-lo mais tarde. Orestes, que é banido do reino, no exílio consulta o oráculo de Delfos, querendo saber se deveria ou não vingar o pai, e obtém a seguinte resposta: olho por olho, dente por dente. Decidido a se vingar, espalha a notícia de sua falsa morte, entra no palácio disfarçado e mata Egisto e Clitemnestra, sua própria mãe, que antes do golpe fatal mostra-lhe o seio e pergunta-lhe como poderia ele ter coragem de matar quem o amamentou. Orestes parece hesitar, mas, ao final, consuma o ato e se justifica dizendo que por um dever de justiça cometeu o assassinato da própria mãe.

A culpa que os Atridas carregam pelos atos de seus antepassados será objeto de discussão na terceira peça, Eumênides, na qual se busca uma resposta à seguinte indagação: Orestes deve ser punido por vingar a morte do pai ou deverá ser poupado ainda que, para vingar-se, tenha matado a própria mãe? 
Com adiante será detalhado, o assunto é levado ao conhecimento de Atena, a deusa da sabedoria e expressão também da justiça, que institui um tribunal $^{10}$ para julgar Orestes, no qual as Erínias ${ }^{11}$ irão atuar como acusadoras $^{12}$, porque são as deusas da vingança, sendo o júri composto por doze cidadãos de Atenas e presidido pela própria Pala Atena. Ao final, depois da acusação e da defesa de Orestes, que tenta justificar seu ato, são colhidos os votos e o resultado é um empate ${ }^{13}$, cabendo a Atena desempatar ${ }^{14}$, quando então decide em favor de Orestes, absolvendo-o, ao proferir as seguintes palavras: "Ele foi absolvido de um crime de morte! Os votos dividiram-se em somas iguais" (Ésquilo, Eumênides, 2016).

Com efeito, como lembra Neves (2015, p. 154), a trilogia de Ésquilo começa em Agamenon, que se passa no escuro Palácio dos Atridas e termina com Eumênides, no luminoso tribunal Areópago de Atenas, sacramentando a passagem das trevas para luz. Trata-se, como diz o autor, de uma conquista da humanidade, promovendo-se o salto do mundo

10 Eis as palavras de Atena ao convocar o conselho de sentença: "Nem opressão, nem anarquia: eis o lema que os cidadãos devem seguir e respeitar. [...] Proclamo instituído aqui um tribunal incorruptível, venerável, inflexível, para guardar, eternamente vigilante, esta cidade, dando-lhe um sono tranquilo. Eis a mensagem que vos quero transmitir, atenienses, pensando em vosso futuro. Levanta-vos agora de onde estás, juízes, e decidi com vossos votos esta causa" (Esquilo, Eumênides, 2016).

11 Também chamadas de Fúrias, eram deusas com a missão de perseguir aqueles que cometiam crime de sangue e que ao final do julgamento de Orestes transformam-se em Eumênides, assumindo nova missão: manter a ordem ditada pela razão humana.

12 O julgamento obedece ao devido processo legal, com garantia do contraditório, o que fica evidenciado nas palavras, dirigidas às Erínias, por Atena: "Quero dizer-vos que agora a palavra é vossa e declarar que estão abertos os debates. Falando em primeiro lugar, o acusador dever instruir-nos claramente sobre os fatos" (Ésquilo, Eumênides, 2016).

13 Um dos argumentos em favor da absolvição de Orestes sai da boca do próprio deus Apolo, ao sustentar que Orestes não cometera crime contra o próprio sangue: "Aquele que se costuma chamar de filho não é gerado pela mãe - ela apenas é nutriz do germe nela semeado -; de fato, o criador é o homem que a fecunda; ela, como uma estranha, apenas salvaguarda o nascituro quando os deuses não o atingem" (Ésquilo, Eumênides, 2016). Ou seja, a fala de Apolo revela a concepção - que, hoje, classificaríamos como misógina - de que o papel da mulher na geração da vida era absolutamente irrelevante, concepção, aliás, que teria se instituído já na sociedade arcaica, visto que presente na mitologia grega, fonte da dramaturgia de Ésquilo, e que persistia em sua época. Como exemplo disso, o deus grego cita a origem da própria Atena. De acordo com a mitologia grega, Zeus engoliu Métis, sua primeira mulher, quando já estava grávida de Atena. Tempos depois, quando chegou a hora do nascimento da deusa, Zeus sentiu uma forte dor de cabeça e ordenou a Hefesto, o deus do fogo, que lhe abrisse a cabeça e de lá saiu Atena já crescida e armada. Ou seja, segundo a linha de defesa, de Orestes, pela voz de Apolo, a mãe seria apenas uma incubadora e, nesse sentido, o filho não carregaria o seu sangue, daí porque à luz da lei, Orestes não teria cometido um crime contra o próprio sangue, ato reputado como indigno e imperdoável. Nessa mesma linha de raciocínio, Clitemnestra também não teria cometido um crime contra o próprio sangue ao matar Agamenon.

14 Em verdade, não se trata de um voto de desempate, mas, sim, de antecipação de voto, como adiante se demonstrará. 
irracional para o mundo jurídico, onde o devido processo legal, contraditório e ampla defesa passam a prevalecer na apuração da responsabilidade penal. Se, antes, o homicídio era indesculpável para as Erínias, independentemente das circunstâncias, agora faz-se necessário que o crime seja submetido a um julgamento, no qual se confira a oportunidade de defesa ao réu:

Há, como se vê, a instauração de uma nova ordem. A antiga Lei do Talião, a punição familiar (do guénos), defendida pelas Erínias, perde espaço. A nova lei vem de Apolo, deus das luzes, em prol da cidade e da civilização. [...] O novo direito ignora a maldição familiar, desconsidera a lei de Talião. As Erínias reclamam a aplicação da antiga lei, pela qual "as gotas de sangue derramado na terra exigem outro sangue". A nova lei, diferentemente, trata da culpabilidade individual, aprecia a consciência do agente $\mathrm{e}$ as circunstâncias do ato. [...]. Trata-se de uma conquista da humanidade (Neves, 2015, p. 156-157).

Se em Agamenon e Coéforas prevalecia a justiça (vingança) privada, com Eumênides, esse método de resolução de conflito chega ao fim, dando lugar a um julgamento democrático, com a apreciação individual da culpa, a análise das circunstâncias do ato e dos valores envolvidos, naquilo que Ésquilo denominou de passagem das trevas para a luz. A partir de então, as Erínias perdem a função e a competência de julgar os crimes de sangue.

Para Karam, "a trilogia de Ésquilo retoma o mito dos atridas para representar o advento do direito no contexto da democracia ateniense" (2016, p. 89), acrescentando, ainda, que "trata-se, portanto, de exaltar a polis, concebida como modelo de justiça e de ordem e como meio de reconciliação dos problemas sociais e morais do homem" (2016, p. 90), além de se constituir, mesmo que sob a perspectiva da mitologia e da literatura gregas, numa representação “da passagem da irrefreável vingança privada familiar à retribuição pública, pois a punição deixa de ser exercida sob a égide da vingança familiar e um conselho de juízes, formado por representantes da pólis, assume a responsabilidade da justiça” (2016, p. 80).

É em vista de tais características que o desfecho da trilogia adquire caráter exemplar:

o fim da lei do talião, dessa interminável cadeia de crimes sangrentos, se dá com o restabelecimento da ordem, mas de uma ordem guiada pela razão e que conjuga, no respeito pela justiça, os preceitos dos deuses olímpicos, e, no temor do castigo, a força original das Erínias; uma ordem na qual a 
Lei se satisfaz sem que sobrevenha o caos, em que os arcaicos laços de sangue se ampliam para as relações conjugais e para o pacto instituído pelos cidadãos da pólis (Karam, 2016, p. 91).

É também Karam (2016, p. 91) quem diz que a passagem da justiça da esfera divina para a humana é representada pelo gesto de Atena ao reconhecer que embora se trate de um caso difícil, não compete mais aos deuses e sim aos homens julgá-lo e, ao instituir o tribunal, escolhe o conselho de sentença entre os melhores cidadãos da pólis e os alerta para os procedimentos e os valores a serem observados, de tal sorte que a partir de então caberá ao tribunal e não mais aos deuses a competência para julgar os crimes de homicídio.

O desfecho que porá fim - ou pelo menos se pretende - à maldição dos Atrida já será objeto de especulações em Coéforas, a qual chega ao seu final com uma fala do Coro que, de modo dramático, conjectura sobre o destino da maldição que se abateu sobre a casa dos Atreus, agora em sua terceira etapa, com a morte de Clitemnestra pelo próprio filho. Ali, como gancho para a terceira peça (Eumênides) já se indaga, o que virá em seguida: o fim da maldição ou um novo desejo de vingança? Orestes será punido com a morte em obediência ao mandamento da antiga lei divina que diz que sangue lava-se com sangue? Eis a fala:

Consuma-se a terceira tempestade neste palácio de nossos senhores, causada por seus próprios habitantes. Os filhos de Tiestes, inda infantes, mortos e devorados num banquete iniciaram a sequência horrenda de nossas amarguras; em seguida foi morto o comandante dos Aqueus, um rei assassinado torpemente enquanto se banhava descuidoso. Agora, na terceira vez, chegou - como direi? - o fim? A salvação? Onde se deterá, ou findará a Ira precursora da Vingança (Ésquilo, 1991, p. 137).

De fato, a antiga lei divina dizia que, uma vez que gotas de sangue eram espalhadas pela terra, as gotas sangrentas chamavam um sangue novo. Em Agamenon (Ésquilo, 1991, p. 66), após a morte do comandante dos Aqueus, Cassandra fala dessa sequência fatal quando, fazendo alusão direta a Orestes, diz "mas não há morte sem vingança de algum deus. Virá um dia mais um vingador - o nosso". Em outras palavras, agora já em Coéforas, na voz do Corifeu:, fica clara a motivação de "alguém que mate quem matou” (Ésquilo, 1991, p. 94), pois, “é lei que o sangue, uma vez derramado em plena terra, exija sangue novo. Um assassínio clama em 
altos brados pelas divinas Fúrias vingadoras, para que em nome das primeiras vítimas elas provoquem implacavelmente nova desgraça em seguida à antiga" (Ésquilo, 1991, p. 106-107).

No mito, é certo que Orestes recebeu uma ordem de Apolo para matar a própria e mãe e seu amante, mas Brandão (1984, p. 24) acrescenta novo ingrediente na trama ao lembrar que não se tratava apenas de cumprir a ordem de Apolo. Orestes também estava picado com o aguilhão da lei do guénos, quando, a certa altura, diz: "mas ainda que não fosse por obediência, a obra teria de se realizar. São muitos os motivos que em mim se encontram de acordo...” (1984, p. 24).

Como se vê, em Coéforas, Orestes estava, de fato, sob um dilema: matar a mãe atrairia as Erínias que a vingariam. Por outro lado, se não vingasse o pai, as de Agamenon não o deixariam em paz. Isso fica claro quando, diante da advertência de Clitemnestra para ter cuidado com as cadelas furiosas de uma mãe, Orestes assim respondeu: "e como evitarei a de meu próprio pai se demonstrar hesitação neste momento?” (Ésquilo, 1991, p. 131).

Para Brandão (1984, p. 26), o antagonismo entre as duas forças ${ }^{15}$ é evidente: "de um lado, o antigo passado, o ius poli, a thémis, a lei de talião, são as trevas; de outro, como advogado de Orestes, Apolo encarna o direito novo, o ius fori, a dike, ou seja, a luz". Dizendo de outro modo: "o que vai ocorrer é uma passagem, dado que o direito dos deuses antigos, que habitam as trevas do Hades, está prestes a ser substituído pelo direito dos deuses novos, que habitam os píncaros inundados de luz do Olimpo" (Brandão, 1984, p. 26).

Concluindo, Brandão vai dizer que

o drama reflete, no seu todo, a luta entre a maldição familiar, regulamentada pelo ius polis, isto é, o direito do guénos, e o novo direito que, sem negar a maldição familiar, estabelece novos cânones jurídicos através do ius fori, a dike, quer dizer, o direito humano, que passará doravante, através do Areópago, a legislar acerca dos crimes de sangue" (Brandão, 1984, p. 27).

15 Outra leitura dá conta de que a trilogia narra uma disputa entre o matriarcado e o patriarcado, que, pode ainda ser feita nas seguintes perspectivas: a) a disputa entre matriarcado e patriarcado, quando este último vai vencer; b) a disputa entre as leis antigas e as novas leis, o que representa as reformas jurídicas de Dracon ou de Solon, entre um direito novo e um antigo. 
É que - não custa lembrar - antes do julgamento de Orestes, quem cometia um crime de sangue não tinha direito a julgamento. Tão logo se consumava o ato, era perseguido imediatamente pelas Erínias do morto. Isso fica claro na voz do Coro, em Eumênides, aqui reproduzido conforme Brandão: "Ah! Ainda uma vez achou socorro! Abraçando a estátua de uma deusa imortal, quer ser julgado pelo ato de suas mãos. Impossível o julgamento! Uma vez derramado o sangue materno, é difícil, aí! Fazê-lo voltar às veias. Perdeu-se para sempre, o líquido derramado por terra" (Brandão, 1984, p. 35).

$\mathrm{Na}$ esteira dessa linha de raciocínio, Berveiller (1935, p. 114) destaca que a morte de Clitemnestra pelas mãos do próprio filho é o tipo de crime que transcende em horror todos os outros e que, nesses casos, os "assassinos não agiam por sua livre vontade", vez que se deixassem de punir um crime, "descurariam de um dever sagrado; vingando-o tornavam-se ímpios”.

Não é sem razão que Brandão (1984, p. 23) salienta que a grandiosa trilogia de Ésquilo começa com as trevas (Agamenon) e termina em plena luz, no Areópago de Atenas (Eumênides), porquanto é na última peça da trilogia que se encontrarão as respostas para a indagação, oferecida no final de Coéforas, acerca do que se sucederia após a morte de Clitemnestra.

Institui-se, pela primeira vez um tribunal e o resultado é conhecido: ao final, dando empate, Atena profere voto decisivo, mas já antecipado ${ }^{16}$, que absolve Orestes, o que despertou a reação das Erínias, que, incialmente, inconformadas com o que chamam de desprezo pelas leis antigas e presas ao desejo de vingança, reagem ameaçando a polis e somente depois de muito esforço e poder de persuasão por parte de Atena se convencem que o

16 Eis a origem daquilo que hoje é conhecido como "voto de Minerva", em homenagem à deusa Atena, que entre os romanos se chamava Minerva. Em verdade, Atena não votou exatamente para desempatar, isso porque, antes de iniciar a votação, ela antecipou o voto, anunciando que ele se somaria aos favoráveis a Orestes, mas votaria por último, daí ter prevalecido a ideia de que votou para desempatar, o que não é verdade, como demonstra o seguinte trecho: "Serei a última a pronunciar o voto e o somarei aos favoráveis a Orestes. Nasci sem ter passado por ventre materno, meu ânimo sempre foi a favor dos homens, à exceção do casamento; apoio o pai. Logo, não tenho preocupação maior com uma esposa que matou o seu marido, o guardião do lar; para que Orestes vença, basta que os votos se dividam igualmente" (Ésquilo, 1991, p. 176). Noutras palavras: o voto de Atena não foi proferido ao tomar conhecimento do empate entre os juízes. Em verdade, decidiu antes, ao antecipar o modo como votaria: em favor de Orestes, que para ser absolvido bastaria o empate dos votos, pois o dela se somaria ao dos favoráveis à absolvição. Modernamente, pode-se dizer que Atena decidiu antes e depois foi em busca dos fundamentos. 
veredito foi o melhor para o destino da cidade de Atenas, quando então assumem um compromisso, junto à deusa da justiça, de renunciar ao direito de vingança e passam a assumir nova função.

Como vai dizer Berveiller (1935, p. 120), eis o significado da passagem: "as Erinyas transformam-se nas Eumenodes, as deusas da vingança e do sangue tornaram-se as deusas da beneficência e do perdão. $E$ como se, finalmente, a ordem e a justiça triunfassem sobre a justiça privada, sobre a vingança” (1935, p. 120, grifei).

Ou, nas palavras de Ost (2005, p. 11), "Em Eumênides, Ésquilo faz o relato de como a cidade de Atenas soube inverter a lógica vingadora das Eríneas, procedendo ao julgamento democrático de Orestes, baseando a partir daí a vida social sobre a confiança e a justiça e não mais sobre o medo e o sangue".

Noutro modo de dizer, com a criação do primeiro tribunal para julgar um crime de sangue, institucionalizou-se a justiça. Antes disso, quem quer que cometesse tal tipo de crime não seria submetido a um julgamento justo, pois seu destino já estava traçado por uma lei divina antiga: quem mata, se credencia como a próxima vítima, dando sequência à maldição do guénos. Não havia julgamento, a condenação já estava dada e a execução era sumária ou demoraria o tempo necessário para sua realização.

Nesse sentido, o julgamento de Orestes representa a passagem do estado de natureza selvagem para o estado civilizatório, e a função de julgar vai ser exercida por um tribunal que atuará como terceira instância e que se posicionará equidistante do autor do crime e da vítima, condição necessária para estabelecer uma punição que reflita uma relação de proporcionalidade entre o ato e o dano causado. Enfim, Atena propõe aquilo que Ost vai chamar de uma saída completamente diferente para o conflito, algo que irá romper com o paradigma até então estabelecido, tratando-se de uma espécie de revolução copernicana, dada a sua radicalidade: "a justiça, enfim, substitui a vingança, a deliberação ultrapassa a violência, enquanto o tempo da memória é substituído pelo perdão" (Ost, 2005, p. 140).

Até então era como se o tempo andasse para trás, porquanto, longe de experimentar o novo, não se fazia mais do que confirmar o velho, cumprindo um dever que estava escrito na memória do crime e que era transferido de geração a geração, recaindo sobre quem tinha o dever de dar 
continuidade à pesada sina de preservar a amarga lembrança de um assassinato que deveria ser vingado, numa lógica em que não vingar equivalia a cometer uma verdadeira injustiça.

Esse é, então, o papel exercido pelo Direito nos modernos sistemas penais, que, diferentemente do que ocorre na justiça privada - em que o autor do crime e a vítima não guardam a distância necessária -, por meio do processo, garante uma equilibrada distância entre o crime e a punição, pois, como ressalta Ost (2005, p. 166), "o processo é, antes de tudo um recuo, uma separação, uma mediatidade", ao contrário da vingança privada que pressupõe a imediatidade.

Nesse sentido, Ost salienta ainda que:

Por essa tomada de distância, socialmente instituída, o processo realiza a intervenção do terceiro árbitro numa querela que será, daqui para frente, triangulada, e então, assim verbalizada, referente a uma lei afetando as partes. $\mathrm{O}$ juiz é separado das partes, assim como o poder judiciário está em posição terceira em relação aos dois outros poderes, em que o Estado se destaca da sociedade civil. [...] Enfim, a sentença só é pronunciada no final de um debate público e contraditório, no decorrer do qual a vítima e suspeito tiveram sucessivamente a palavra, tornando-se assim um e outro, os atores de seu processo (2005, p. 166).

Dentro da ideia de Ost, o processo penal é, portanto, o instrumento que melhor simboliza a passagem do tempo da memória, no qual o crime não é esquecido, para o tempo do perdão, em que há uma compensação que também tem o efeito de produzir o esquecimento, de interromper o ciclo de vingança. Ocorre que essa passagem, contudo, não completou seu ciclo, como se verá em seguida.

\section{Cena II: a passagem (in) completa - as fúrias ainda clamam por vingança}

Certamente que, no seu sentido absoluto, a vingança privada hoje é um recurso vedado em qualquer ordem jurídica moderna, mas o que importa aqui saber é se tal interdito representou o fim das maldições familiares marcadas pela síndrome da maldição dos Atridas e se extinguiuse a vingança - ou pelo menos seu desejo - como ato reparador do mal causado pelo ofensor. Em resposta à primeira parte da indagação, pode-se dizer que o testemunho cotidiano da ordem dos acontecimentos aponta para o fato de que crimes de sangue ainda acontecem e que não há nenhum indicativo de que um dia desaparecerão 
Com efeito, Brandão (2011, p. 110) defende que o julgamento de Orestes por um tribunal não marca nem mesmo o fim da maldição dos Atridas no âmbito espaço-temporal da Grécia antiga, porquanto, segundo ele, "após as núpcias de Orestes com Hermíona, Electra casou com Pílades e a maldição dos filhos de Atreu continuou", dando origem ao ciclo de fatalidades que "serviu de banquete trágico a nove grandes tragédias que chegaram até nós”.

De fato, nos tempos atuais, diariamente se tem notícia da multiplicação da maldição dos Atridas, ainda que não necessariamente com suas características originais: o ciclo de vingança que se sucede, de geração a geração, dentro da mesma estirpe, embora com as mesmas motivações (disputa por poder, traição, adultério, estupro, canibalismo, ganância, violência, parricídios, matricídios, dentre outros motivos torpes, vis ou cruéis), tende a ser, hoje em dia, logo interrompido ou mal se inicia ${ }^{17}$. Isso deve ser creditado à vedação da justiça privada (vingança) e à ausência de um deus com o poder de julgar os homens, muito embora desejos de vingança ainda rondem a sociedade e, não é exagero afirmar, assim como os vestígios do velho sistema vindicativo.

Quanto à indagação sobre a extinção da vingança, que nos interessa mais de perto, não é temerária a afirmação de que a passagem para um sistema penal tenha se dado de forma incompleta, no sentido que teria se institucionalizado sem restrições.

Se mais de dois mil anos já se passaram, ainda seria possível afirmar que o julgamento de Orestes é realmente representativo do fim do ciclo de vingança como forma de realização de justiça ou, ao reverso, mais verossímil seria dizer que os sistemas modernos de direito, com seus processos civilizados de punição, ainda refletem os primitivos sistemas vindicativos, numa palavra: as três gotas de sangue, no que pode se chamar de as mães fundadoras, de Urano, que foram derramadas sobre a terra e que deram origem às deusas vingadoras, ainda tingem-na e por conta disso vive-se um passado que não passa?

17 Às vezes, o ciclo de vingança se prolonga até que o Estado intervenha. Dependendo de sua agilidade, o ciclo pode ser interrompido no início ou após sucessivas mortes movidas pelo desejo de vingança. 
No princípio, punir não é nada mais do que recordar e retribuir, é dar o troco, vai dizer Ost (2005, p. 121), que se lança a fazer uma série de indagações, do tipo: guardaria o direito penal moderno alguma relação com o obscuro passado de vingança? Teria ele se livrado definitivamente de toda ideia de represália como se tivesse abandonado a lei de Talião a um passado distante, atualmente tido apenas como parte da pré-história jurídica, hoje totalmente ultrapassada?

Para Ost, a resposta passa pela análise das três funções da pena nos sistemas penais contemporâneos ${ }^{18}$ e que estão relacionadas diretamente com dimensões temporais distintas: preventiva, voltada para o futuro; reparadora, com foco no presente; por fim, retributiva, ancorada no passado e que seria um modo de prolongamento do antigo sistema talião. Se, por meio da prevenção, o objetivo da pena volta-se para o futuro, no sentido de impedir um comportamento indesejável para a comunidade; a reparação tem como objeto de preocupação a vítima em si, a quem procura compensar pelo dano sofrido. Por fim, quanto à retribuição, trata-se da mais antiga finalidade da pena: “se é verdade que 'retribuir é dar o troco', a função retributiva da pena supõe uma concepção da justiça, com o eixo no mal do passado (a infração), ao qual nos declinamos a fazer corresponder o mal equivalente (a pena)" (2005, p. 121-122).

Conforme Ost (2005, p. 123), a dimensão retributiva da pena está presente no direito contemporâneo, razão pela qual seria conveniente que se compreendesse o sentido e, mais ainda, o alcance da questão temporal que está em jogo quando a questão é saber se trata-se de lei de talião, de sacrifício ou de vingança.

Prosseguindo em sua aguda análise, Ost afirma que falar de vingança e da lei de Talião não é nada fácil, de tanto que se acumularam a seu respeito ideias falsas e condenações, mas deixa claro que, sendo uma lei universal, o talião se presta a leituras contrastantes, como a que vê nela

18 Como se verá adiante, Oliver Wendell Holmes (1963) também vai tratar da teoria que fundamenta a pena. 
uma forma regressiva de violência - quando se pensa na violência privada, sem controle e interminável - ou quando, ao contrário, é analisada como uma figura, ainda que rudimentar, sólida e legítima de instituição justiceira, que se traduz “seja por um sistema ‘vindicativo' civilizado e reconciliador ${ }^{19}$, ou por um princípio racional de compensação aplicado por tribunais embrionários" (2005, p. 123-125).

Para Ost, a vingança, como aparente sistema de justiça (privada) não passa de uma via de fato "que decuplica a violência ao invés de apaziguá-la" (2005, p. 124), pois lhe faltaria, tal como ocorre na justiça pública, o necessário distanciamento dos fatos para a reflexão e a mediação de terceiro, sem os quais a justiça não se revela coma sua melhor luz. Assim,

\begin{abstract}
A vingança procede do imediatismo: ela surge de um impulso não refreado, ela exige uma represália imediata. Sem dúvida, nem sempre é saciada de imediato: nesse caso, ela se nutre de rancor, 'como se a ofensa inicial tivesse feito nascer um crédito, que se tratasse de recobrar com ágio'. Tudo isso passa, então, como se os relógios tivessem parado na hora da ofensa e que o futuro não apresentasse outra perspectiva além da ruminação neurótica do crime e a esperança de sua anulação simbólica. $\mathrm{Na}$ resolução vingativa, o tempo se petrifica no espaço fechado do momento passado da ofensa, do qual o presente e o futuro permitem apenas a repetição obsessiva (Ost, 2005, p. 124).
\end{abstract}

Ainda segundo Ost (2005, p. 125), a vingança é prisioneira do tempo, pois a incapacidade de sair de um congelamento fechado e repetitivo e de passar para outro tempo corresponde também à incapacidade de se submeter a uma instância social, que, assumindo a função de terceiro, possibilita triangular o conflito e, desse modo, resolvê-lo, pacificando-o duradouramente.

Que o julgamento de Orestes é representativo, pelo menos figurativamente, da passagem da justiça privada para a pública, disso ninguém tem dúvida. Todavia, o que não se pode ignorar são os bafejos do ranço da vingança, cujo sopro chega a nossos dias. É como se as deusas vingadoras nunca tivessem se convertido nas deusas benevolentes e permanecessem presas ao dever de clamar por vingança.

19 Esse sistema não seria nada mais do que o processo penal, como se verá adiante. 


\section{TERCEIRO ATO: A DIFICULDADE DE DESLIGAR O PASSADO}

Cena I: vestígios de vingança nos modernos sistemas de direito ou de como as cadelas vingadoras ainda ladram um passado que não passa

Não somente vestígios, mas também a presença, de um rudimentar sistema de reparação de erros, que, reconheça-se, passou por diferentes estágios evolutivos, ainda se fazem sentir não só no imaginário das pessoas comuns. E não é só: ressoam sobre os modernos sistemas de direito e instituições responsáveis pela administração de conflitos.

Nesse sentido, um olhar atento nos levará à conclusão de que a famosa lei de talião representou uma evolução, se tomarmos em consideração o significado de seu principal enunciado ("olho por olho, dente o por dente”), a pressupor uma relação de equivalência. A evolução parecerá evidente à medida que, anteriormente, não existia uma relação de proporcionalidade, visto que a perda de um olho poderia acarretar a punição do agressor com a própria vida, pois a tanto estavam legitimados os familiares e a própria vítima.

Na mitologia grega, já se demonstrou, isso vai mudar com a fabulação do primeiro julgamento realizado por um tribunal, o de Orestes, que, simbolicamente, representa o fim da justiça privada. De lá para cá, no mundo empírico, entra em cena o sistema da justiça pública, que vai evoluir até encontrar seu apogeu na modernidade com o positivismo jurídico que, no seu primeiro momento e influenciado pelas ciências exatas, procurou construir uma linguagem rigorosa para o direito e viveu a ilusão de que se bastaria, pois, nesse cenário, todo e qualquer julgamento, com base na letra da lei inscrita nos códigos, estaria livre de qualquer critério subjetivo ou irracional. Claro que, nem tudo saiu como esperado, mas o que importa aqui é registrar que tudo indica que se trata mesmo de uma linha evolutiva, senão vejamos: em nome de uma racionalidade, a justiça pública (julgamento de Orestes) substitui a justiça privada que, em certo sentido, tinha substituído a justiça divina.

Sendo assim, e a título de conclusão dessas considerações gerais, pode-se dizer que a subjetividade insiste em se fazer presente nos sistemas de justiça, seja ela pública ou privada, e, em certa medida, o modo de ser desta última ainda ecoa nos modernos sistemas de justiça pública. 
Tudo isso porque, como aponta Joana Aguiar e Silva (2008), ainda convivemos com vestígios da justiça privada e dos sistemas vingativos nos modernos sistemas públicos de administração de conflitos, eis o ponto de chegada dessas considerações iniciais.

Com efeito, Aguiar e Silva (2008, p. 132) chama atenção para o fato de que não é nova "a ideia de que a realidade jurídica que hoje conhecemos e em que nos movimentamos, resulta, de alguma forma, de um processo de civilizada estilização dessa juridicidade taliônica, por sua vez uma estilização daquele vindicativo sistema de punição privada ilimitada”. Acrescenta a autora que, nesse referido sistema, profundamente simbólico e ritualista, a vítima ou seu grupo familiar, em conjunto ou separadamente, vinga-se retribuindo o mal ao autor da ofensa e/ou a membros do seu grupo, sendo essa agressão, ela mesma, geradora de novas agressões e de novas vinganças, que se alternam em cadeia num ciclo sem fim.

De acordo com Aguiar e Silva (2008, p. 132), pode até parecer questionável tais práticas, mas a verdade é que a própria sobrevivência do grupo social exige a instituição de sistemas canalizadores do exercício de vingança, e o fato de a Lei de Talião ser consagrada tanto no Código de Hamurabi quanto na Bíblia comprova isso. É certo que, em dado momento da história e para certos crimes, segundo a autora citada, a vingança foi substituída por fórmulas diferentes, como as ordálias e o duelo, mas, em algumas sociedades, às portas da modernidade, crimes continuaram a constituir, para a vítima ou sua família, um direito de vingança.

Citando Oliver Wendell Holmes, justiçe da Suprema Corte de Justiça dos EUA, Aguiar e Silva lembra que o mais ardoroso defensor do realismo jurídico americano "defendia também a ideia de que a origem de todo o direito radica precisamente na vingança, no sentimento e nas práticas de vingança" (2008, p. 133) e que "os actuais ordenamentos jurídicos, com as características e atributos que lhes reconhecemos, mais não seriam, segundo o eminente magistrado, senão o resultado final de um processo evolutivo com início nesse rudimentar modo de resolver conflitos sociais que subjaz ao sistema vindicativo" (2008, p. 133).

De fato, em 1881, data da primeira publicação de The Common Law, Oliver Wendel Holmes já lembrava um fato bastante conhecido: o de que as primeiras formas de solução jurídica para os casos se baseavam na 
vingança. Diz ele que "autores modernos afirmam que o direito romano originou-se das lutas de sangue e todas autoridades concordam em que assim começou também o direito germânico" (Holmes, 1963, p. 30). E isso não somente em relação ao direito penal, que é a norma estatal que pune os delitos, como se poderia, a princípio, imaginar. É que, de igual modo, o sentimento de vingança também inspirou o direito privado, como ele afirma:

os princípios originais da responsabilidade pelo dano causado a outra pessoa ou coisa foram, até agora, menos cuidadosamente considerados do que os que disciplinam o delito. [...] Tentarei demonstrar que também esta responsabilidade teve suas raízes na paixão da vingança e indicar as mudanças através das quais ela chegou à sua forma presente (Holmes, 1963, p.30).

Holmes (1963, p. 34-37) vai demonstrar que, nos antigos sistemas primitivos, eram julgados e punidos também animais, escravos (que não eram concebidos como pessoas, relembre-se) e, até mesmo, seres inanimados, propriamente ditos, o que era comum entre judeus, romanos e gregos. Para ele, o fato de seres inanimados serem objeto de repercussão penal ou de responsabilização na esfera civil só poderia ser justificado à medida que eram personificados, sem o que a raiva a eles dirigida teria duração transitória.

Como o próprio Holmes (1963, p. 56) afirma, ao trazer esses exemplos, seu propósito é o de demonstrar que as várias formas de responsabilidade conhecidas pelo direito moderno - sejam elas civil ou criminal - emergiram de fonte comum: a vingança, que, obviamente, é muito mais forte e enraizada no direito penal do que no direito civil.

A propósito, em relação ao Direito Penal, Holmes destaca que, nesse ramo, muito mais claramente, a responsabilização do infrator é filha da vingança e que a satisfação do seu desejo jamais deixou de ser o objetivo da punição:

O desejo de vingança denota a opinião de que seu fim é condenar real e pessoalmente. Condena sua vítima pela adoção de uma norma interna, não objetiva ou externa. A questão se apresenta assim: tal regra é ainda aceita, em sua forma primitiva, ou em desenvolvimento um pouco mais apurado, como habitualmente se supõe e não parece impossível, considerando-se a relativa lentidão com que se aperfeiçoa o direito criminal (Holmes, 1963, p. 58). 
Para Holmes (1963, p. 58), o desejo de vingança, que é subjacente à punição, fica mais evidente em situações em que a compensação pela ofensa está fora de questão, como é o caso do homicídio, no qual, por conta do desaparecimento do ofendido, a indenização, pelo menos à pessoa dele, torna-se impossível. Outra hipótese é quando não existem meios de se forçar a indenização, o que ocorre nos casos em que os infratores são hipossuficientes financeira e economicamente. Em todos esses casos:

\begin{abstract}
a punição se situa como uma alternativa. Um sofrimento pode ser infligido no infrator, de forma que não restaure, na parte injuriada, sua situação anterior, mas que é infligido pelo verdadeiro propósito de causá-lo. $\mathrm{E}$ até onde esta punição substitui a compensação, seja em virtude da morte da pessoa ofendida, do número indefinido de pessoas afetadas, ou da impossibilidade de calcular-se o valor do sofrimento em dinheiro, seja por causa da pobreza do criminoso, pode-se dizer que um dos seus objetivos é satisfazer o desejo de vingança. O prisioneiro paga com seu corpo (Holmes, 1963, p. 58).
\end{abstract}

Adiante, o justice norte-americano revela-se mais incisivo, ao declarar que o próprio legislador reivindica uma pretensão de vingança quando, com seu ato $^{20}$, não somente chancela, como deve chancelar, a satisfação da desforra como objetivo, um fato que, de todo modo, faz com que compartilhem da mesma opinião "duas autoridades tão grandes como Bishop Butler e Jeremy Bentham, tão opostos em outros pontos de vista"21, acrescentando ao final: "Sir James Stephen disse: 'O direito criminal está para a paixão da vingança na mesma relação que o casamento para o apetite sexual"”22 (Holmes, 1963, p. 59).

O que Holmes sugere, ao que tudo indica, é que a lei foi a forma civilizada encontrada pelo homem para preservar o exercício do seu desejo de vingança, ainda que de forma dissimulada, um meio menos traumático de canalizar aquilo que no fundo não passaria de vingança. Esse parece ser seu raciocínio quando defende que o primeiro requisito a constar em um corpo de lei sadio é o de correspondência com os reais sentimentos e exigências de uma comunidade, sejam eles justos ou injustos. Para Holmes, é como se não houvesse uma saída, pois "se o povo satisfizesse a paixão de

\footnotetext{
20 Salvo engano o ato a que se refere é a elaboração da lei.

21 Além de filósofos ingleses, Bishop Butler foi bispo anglicano, e Jeremy Bentham, jurista renomado e um dos corifeus do utilitarismo.

${ }^{22}$ Sir James Stephen foi um político inglês que ocupou o cargo de subsecretário colonial.
} 
desforra fora da lei, caso esta não o apoiasse nisto, não lhe restaria escolha senão satisfazer, ela própria, tal desejo", de sorte a "evitar, desta maneira, o mal maior da retribuição privada" (Holmes, 1963, p. 59), tal como ocorria na Grécia antiga, cujo contexto transparece na representação das práticas que antecedem o julgamento de Orestes.

A propósito dos fundamentos do direito de punir, interessante é o pensamento de Tobias Barreto, veiculado na clássica obra Estudos de filosofia, reeditada em 1977. Para Barreto (1977, p. 358), citando Herman Post, "não é um erro afirmar que, primitivamente pena e sacrifício humano foram uma e a mesma coisa, e que destarte a origem do direito de punir deve ser procurada nesse mesmo sacrifício", sem dizer que tanto é certo que essa ideia sempre esteve na origem da pena quanto que ainda hoje essa mesma ideia se faz acompanhar da execução de qualquer pena (Barreto, 1977, p. 368)

Claro que já não passa de uma miragem a ideia de que, ao punir, o Estado tem como finalidade aplacar a ira dos deuses, fazer calar as deusas da vingança, reproduzindo assim o que é representado no julgamento de Orestes, quando elas se convertem em Eumênides, graças ao espírito conciliador de Atena. Note-se, entretanto, que o processo de conversão não se dá sem maiores traumas, pois as Erínias reagem com vigor à ideia de serem institucionalmente incorporadas e é somente graças à habilidade da deusa Atena que, ao final, são convencidas. Todavia, muito embora não mais se invoque, nos dias de hoje, a presença das Fúrias para punir com a vingança o crime de sangue, como indica Barreto, no fundo, esse sentimento está apenas adormecido:

Não se diz mais, é verdade, querer-se aplacar, com o castigo infligido ao criminoso, os deuses irritados, ou serenar as manes da vítima da vítima do crime, mas quase que se procede de acordo com essa intuição, guardadas apenas as diferenças determinadas pela cultura ulterior. [...] Podem frases teoréticas encobrir a verdadeira feição da coisa, mas no fundo o que resta é o fato incontestável de que punir é sacrificar - sacrificar em todo ou em parte, o indivíduo ao bem da comunhão social - sacrifício mais ou menos cruel conforme o grau de civilização deste ou daquele povo nesta ou naquela época dada, mas sacrifício necessário, que, se por um lado não se acomoda à rigorosa medida jurídica, por outro lado também não pode ser abolido por efeito de um sentimentalismo humanitário, que não raras vezes quer ver extintas por amor da humanidade coisas, sem as quais a humanidade não poderia talvez existir (Barreto, 1977, p. 358-359). 
Barreto (1977, p. 359), diferentemente de outros teóricos, postula que o primeiro momento histórico da pena é o sacrifício, além da expiação, que lhe conferia um caráter religioso, mas, mesmo nesse momento, já se faz presente o sentimento de vingança e, ao mesmo tempo em que vai diminuindo o lado religioso da expiação, "aumenta o lado social e político da vindicta, que permanece ainda hoje como predicado indispensável para uma definição da pena”.

Compartilhando do pensamento de Holmes, Barreto considera que a ideia de vindita - a qual durante muito tempo prevaleceu no direito penal romano e se estendeu mesmo a épocas muito posteriores - ainda não foi afastada, como pretendem fazer entender algumas teorias do direito de punir, porquanto elas não fazem outra coisa senão "procurar prender às leis da racionalidade moderna uma velha coisa bárbara e absurda, posto que necessária, qual é a pena, sem que daí resulte a mínima alteração na natureza do fato" (1977, p. 360).

Barreto, para longe das reflexões metafísicas, deixa claro que os fatos é que são determinantes, são eles que vão traduzir o sentimento de uma comunidade, que nunca vai deixar que seus atos sejam determinados por ideias abstratas e destituídas de qualquer paixão. Nessa linha de raciocínio, para determinada comunidade, o sentimento de justiça, por si só incapaz de dar origem à instituição da pena, confunde-se com o sentimento de vingança, como se fossem uma coisa só. Para o autor citado, o momento subjetivo do direito de punir não foi abolido nem absorvido pelo poder público, nem mesmo nos estados mais modernos, "onde existe reconhecido o direito individual da queixa ou o direito de promover a acusação criminal por uma ofensa recebida, a qual nada mais nem menos importa do que o reconhecimento da justa vindita do ofendido" (1977, p.362).

Com efeito, existem sociedades modernas que adotam, sem maiores receios, a pena de morte como punição para a prática de crimes de homicídio, dentre outros, assim como o instituto da queixa-crime do ofendido e a figura do assistente da acusação que, no fundo, não representam outra coisa senão uma espécie de vingança pública ou de vingança privada assistida pelo Estado, no caso das duas últimas hipóteses.

E é o próprio jurista brasileiro quem indaga: “com efeito, mesmo na ora presente, o que vem a ser em última análise a imposição, por exemplo, 
da pena de morte a um delinquente, senão uma espécie de sacrifício a um novo Moloch, a um ignoto deo ${ }^{23}$ da justiça, que se pretende ser vingada e satisfeita?” (Barreto, 1977, p. 358-359).

Para Barreto (1977, p. 367-368), o direito penal positivo, de uma forma geral, atravessou três fases: a inicial, na qual predominou o princípio da vindicta privada, agregando-se, dependendo do lugar e da época, a expiação religiosa; a fase intermediária, que surge como transitória e consiste basicamente na ideia de composição, ou seja, a vingança sendo satisfeita por meio de indenização pecuniária para, ao final, dar origem à terceira etapa, a atual, que, fundada no direito social de punir, é exercida através do Estado, que impõe uma punição pública.

De todo modo, sempre haverá, nos modernos sistemas de direito, os resquícios dos primitivos sistemas punitivos, pois, como destaca Barreto (1977, p. 368), em consonância com Holmes, mesmo "no direito criminal hodierno, por mais regular que pareça sua estrutura, encontram-se ainda sinais de primitiva rudeza”. Nesse sentido, o jurista brasileiro adverte que “o princípio da vindicta ainda não desapareceu de todo de nenhum dos atuais sistemas de penalidade positiva" (1977, p. 368), sendo a subordinação de determinados crimes à formulação da chamada "queixa do ofendido" um dos elementos indicativos do reconhecimento desse princípio.

Adiante, revelando perfeita sintonia com o entendimento de Holmes (quando este refere que lei é a forma civilizada de canalizar o sentimento de vingança), Tobias Barreto menciona que:

Todo sistema de força vai atrás de um estado de equilíbrio; a sociedade é também um sistema de forças e o estado de equilíbrio que ela procura, é justamente um estado de direito, para cuja consecução ela vive em contínua guerra defensiva, empregando meios e manejando armas, que não são sempre forjadas segundo os rigorosos princípios humanitários, porém que devam ser sempre eficazes. Entre estas armas está a pena (Barreto, 1977, p. 368)

Enfim: sistemas primitivos ainda reverberam nos dias de hoje e, como sugere Aguiar e Silva (2008, p. 135), a questão que deve ser colocada é saber se atualmente vivemos sob os auspícios de uma juridicidade que pode ser considerada herdeira do sistema vindicativo, se é possível desenhar uma

\footnotetext{
23 Expressão latina que significa “deus desconhecido”.
} 
linha evolutiva entre sistemas primitivos vindicativos e os nossos modernos sistemas de direito. Para a autora, uma reflexão mais atenta viabiliza constatar que tal herança está mais presente na nossa consciência do que se imagina, o que não deixa de ser um paradoxo, pois contraria a ideia de evolução. É inegável, no entanto, que

Nas muitas reportagens, histórias e comentários que, nos
dias que correm, a dinâmica da vida judicial suscita, justiça
parece ser uma noção recorrentemente invocada. Nos
discursos e entrevistas que jornalistas as mais das vezes
pouco tirocinados e ávidos de sensacionalismo produzem à
boca dos tribunais, instando magistrados, causídicos ou,
mais frequentemente ainda, simples curiosos/interessados a
dizerem o que pensam, a justiça surge como denominador
comum dos múltiplos registros discursivos que no contexto
se manifestam. [...] Aquilo que muitas vezes transparece
quando ouvimos um certo tipo de comentários,
nomeadamente feitos por aquela última categoria de
"interessados" nas lides, é que as pessoas quando falam em
justiça têm em mente - ainda que inconscientemente - uma
justiça essencialmente vindicativa. [...]. Quantas vezes não
ouvimos comentar a propósito de determinados criminosos,
acusados da prática de determinado tipo de crime, que lhes
deviam fazer a mesma coisa? (Aguiar e Silva, 20o8, p. 133-
134, grifos meus).

Segundo Aguiar e Silva (2008, p. 143), a grande vantagem de um sistema público retributivo reside na preservação da ordem pública, mas é ilusão imaginar que ele irá eliminar os instintos mais primitivos e/ou inspirados em leis taliônicas, mesmo porque a história é testemunha de que "o impulso de vingança face a uma injustiça é um dos mais duradouros aspectos do espírito humano, que nem a mais duras penas pode erradicar". O problema, como adverte a autora citada, é que, se a sociedade substitui o indivíduo na imposição do castigo, nesse momento ela assume a responsabilidade perante o conjunto de cidadãos - e, de igual modo, perante as vítimas do crime -, o que também é uma maneira de prestar contas, e por essa razão mesma tem que exercer tal função de forma competente, oferecendo as respostas corretas de forma eficiente e com respeito às leis e à Constituição Federal, caso contrário assume o risco de as pessoas, diretamente, sentiram-se no direito de fazer justiça pelas próprias mãos, numa palavra: vingando-se.

Doutra parte, Aguiar e Silva (2008, p. 143) engrossa o coro de muitos ao comentar que, quando as pessoas falam em justiça, nas entrelinhas, o desejo é outro, querem mesmo é vingar-se, ainda que nem todos tenham a 
coragem de reconhecer isso e nem façam a alegria dos repórteres policiais da mídia.

De fato, de modo geral, pode-se dizer não só que o desejo de vingança, como sinônimo de realização de justiça, ainda está presente no imaginário das pessoas, mas, igualmente, que ele se faz representar em vários sistemas contemporâneos de direito por meio de diversos institutos. Uma dessas hipóteses é o que ocorre na legislação penal processual brasileira na figura do assistente de acusação, tida por alguns especialistas como um exemplo típico dessa prática, cuja existência serviria - e para isso alguns estudiosos afirmam que sobram razões - para legitimar a vingança privada no processo penal.

Com efeito, mostra-se inegável que a presença da vítima ou de seus sucessores representados pela figura do assistente da acusação é carregada de sentimentos marcadamente pessoais, emocionais e de vingança, circunstâncias essas que tornam difícil afastar o argumento de que sua presença reproduz, em parte, o sistema vindicativo.

É certo que existe um contra-argumento: o de que a assistência penal prende-se a interesses de ressarcimento ou de recomposição patrimonial, mas sua consistência é, no mínimo, discutível, à vista de outro contraponto que não pode passar despercebido: a pretensão de satisfação dos interesses patrimoniais do ofendido pode ser buscada na via civil, sendo o processo penal meio inadequado para esse fim, daí porque se reforça a tese no sentido de que a presença do assistente de acusação no processo penal prende-se exclusivamente a razões de ordem sentimental, numa palavra: vingança, nada mais.

Nesse sentido, é o entendimento de Azevedo (2009), para quem o assistente de acusação é um desassistido da Constituição - que não o recepcionou -, e que sua manutenção na legislação processual penal não deixa de traduzir um vestígio evidente do fenômeno da privatização do processo penal.

De acordo com o autor citado, a privatização do processo penal deve ser entendida como "o movimento de política criminal que tem por finalidade conferir um papel de destaque à vítima no processo penal, ou seja, tornar a vítima um sujeito do processo, possibilitando à vítima o exercício da vingança” (Azevedo, 2011, p. 326-327). Afinal, 
Sob o argumento de que, por muito tempo, a vítima foi colocada de lado pelo direito processual penal, busca-se, mais recentemente, reverter a todo custo esse quadro, atribuindo, desta forma, à vítima um papel de importância dentro deste ramo do direito. Contudo, ao se proceder, desta forma, macula-se o caráter de direito público do processo penal, desconsidera-se a natureza indisponível dos direitos com os quais lida processo e se sobreleva, em excesso, a busca da satisfação dos interesses da vítima. Aliás, é esse é o entendimento de Salo de Carvalho, ao asseverar que "a assistência ao Ministério Público é um resquício de privatização do processo penal - apesar da falácia sempre invocada de que o interesse não é penal, mas sim dos efeitos civis da condenação...”. [...] Se, é certo, no que toca ao papel da vítima no processo penal, que o Estado toma como seu direito de outrem, também é certo, que não se deve devolver à vítima o direito que foi expropriado. $\mathrm{O}$ que caracteriza um Estado civilizado e democraticamente orientado é, dentre outros fatores, a criminalização do exercício arbitrário das próprias razões (CP, artigo 345); é a construção do conceito de jurisdição, como atividade substitutiva dos interesses das partes; é a incapacidade de sublimação das pessoas envolvidas no conflito, ou seja, de "sair do próprio conflito $e$, ao observá-lo de fora, verificar imparcialmente a resposta adequada ao caso". Portanto, não se deve acreditar tanto nos bons sentimentos humanos (Azevedo, 2011, p. 327328 , grifos meus).

Concluindo, Azevedo (2011, p.328) lembra que "mais do que obter reparação pelos danos sofridos, o que a vítima realmente deseja ver saciado é o seu desejo de vingança, ou porque não dizer, é aplicar o máximo de pena que a lei prevê e admite para o réu, já que o Estado de Direito não lhe dá o direito de matar esse".

A respeito do tema, no mesmo sentido, Lenio Streck afirma: “Agregue-se que é antinômica a presença do Ministério Público, que no júri defende os interesses da sociedade, com a figura do assistente de acusação, que defende os interesses privados da vítima, transparecendo, disso, resquícios de vindita (Streck, 2001, p. 159).

De igual modo pensa Adams (2008, p. 102-114), para quem quando o dono da ação, que é o Ministério Público, desiste da acusação e requer a absolvição do réu, não pode a assistência invocar a condenação, sob pena de regresso à vingança privada ${ }^{24}$. Em suas conclusões, a autora aduz que,

24 Não é assim, contudo, que pensa o STJ - e de modo geral essa é a tendência naquela Corte - em acórdão que, invocando precedentes do STF, confere ampla legitimidade ao assistente de acusação não só para figurar nessa condição, auxiliando o Ministério Público, mas também para recorrer de decisão que contrarie os interesses da vítima ou de seus sucessores, não obstante, o MP, como verdadeiro titular da ação, não recorra, por 
enquanto ramo do direito público, o direito penal não pode consagrar meios privados para que a vítima defenda seus interesses. Para isso existe a esfera cível, cuja amplitude é alargada em relação à esfera penal. Possibilitar ao ofendido reação penal nada mais é que um retrocesso à vingança privada. Isso porque o Estado, ao assumir para si os meios de exercer o jus puniendi retirou do cidadão essa condição, afastando qualquer ambição movida pela emoção e pela busca desmedida de punição (Adams, 2008, p. 102-114).

A figura do assistente de acusação em algumas legislações talvez seja o exemplo mais evidente dos resquícios do antigo sistema vindicativo de justiça, mais a ela agregam-se outras. Aqui, tão somente para fins de ilustração, pode-se evocar o caso da pena de morte, presente em vários sistemas de direito processual penal e que não deixa, também, de ser um exemplo da realização do desejo de vingança, nesse caso pelas mãos de um terceiro. Os familiares da vítima ficam, assim, liberados de exerceram-na pessoalmente e, com isso, atrair para si a maldição dos Atridas, pois da vingança certamente resultaria outra vingança, que, por sua vez, daria azo a uma sucessão sem fim, tal como ocorria na Grécia antiga e se encontra representado na mitologia e literatura gregas. Do mesmo modo, pode-se dizer que os fundamentos do chamado direito penal do inimigo teriam sua origem no sentimento de vingança, assim como a manutenção da queixa do ofendido em determinadas legislações e para determinados crimes.

De igual modo, não seria temerário afirmar, embora o tema seja polêmico, que os efeitos da confirmação da condenação penal em segundo grau de jurisdição, tal como defendeu o Supremo Tribunal Federal recentemente, também pode se somar à lista dos resquícios de vindita, pois, em certa medida, a relativização da presunção de inocência com a prisão após a condenação do réu em segunda instância seria, guardadas as devidas proporções, um reflexo do imediatismo, que é uma das características da vingança.

Numa derradeira consideração, cabe destacar - diante dos resquícios e da presença de vindita que, nos modernos sistemas penais, operam no plano simbólico - que as tragédias gregas permanecem atuais, perpassando os séculos e lembrando-nos que quem se lança contra o próprio sangue - e

exemplo, de uma absolvição. Nesse sentido, ver o acórdão proferido no Recurso Especial $\mathrm{n}^{\mathrm{a}}$ 1.451.720-SP (2014/o097833-1), publicado no DJe em 29.06.2015. 
o sangue humano é um só, independentemente de se tratar ou não do mesmo guéno familiar - atrai a ira dos deuses.

\section{EPÍLOGO}

Ao longo deste estudo, procuramos demonstrar que, além da filosofia, da política, da democracia e do lúdico, os gregos nos legaram a invenção do direito, muito embora tal realidade, no mais das vezes, tenha sido encoberta pela força da nossa formação romano-canônica, o que não apaga o fato de que foi o espírito heleno que concebeu tanto a institucionalização do tribunal quanto a adoção de critérios racionais que pusessem fim ao sistema vingativo da justiça privada, o que nos autoriza a concluir que ali está cravado o marco zero daquilo que, dentro de uma linha evolutiva, tornou-se, nos modernos sistemas de administração de conflito em matéria de persecução penal, a realização do direito.

O diferencial é que o legado grego não nos foi transmitido diretamente pelo direito, entendido como sistema normativo, mas por meio de uma mostra cultural privilegiada: o mito e a arte cênica, especialmente as tragédias, que revisitamos ao longo deste estudo com o objetivo de analisar o que aprendemos e quais as lições que ainda poderemos delas extrair, dado que as questões ali debatidas, há mais de dois séculos, ainda reverberam.

Para esse fim, mergulhamos num tema da mitologia grega trabalhado por Ésquilo - um dos três maiores dramaturgos gregos da antiguidade -, na trilogia denominada Oresteia, na qual é apresentada parte da história da maldição dos Atridas e que culmina com a instituição do tribunal do júri e com a adoção do julgamento racional, de modo a desvincular o sentimento de vingança da ideia de justiça, embora, como demonstrado, a passagem da justiça privada para a justiça pública - simbolicamente representada pela conversão das Erínias em Eumênides - não tenha completado seu ciclo.

Para se chegar a essa constatação, analisamos os sistemas contemporâneos de direito e constatamos que, em seus civilizados processos de punição, ainda há reflexos dos primitivos sistemas vingativos. Numa palavra final: ainda é presente um passado que não passa, como se as longas memórias das deusas vingadoras ainda percorressem os corredores das almas das vítimas e de seus familiares, clamando por vingança, 
interditada, por certo, pelo Estado, mas que, ao exercer o direito público de punir, em dada perspectiva, não faz outra coisa senão reproduzir sentimentos e práticas de vingança, a recordar a maldição dos Atridas, mesmo depois de passados mais de dois mil anos da fabulação do julgamento de Orestes.

\section{REFERÊNCIAS}

ADAMS, Aline. A flagrante incompatibilidade entre o instituto da assistência à acusação e a Constituição Federal de 1988. Revisa Eletrônica do Curso de Direito da UFSM, v. 3 n 3, p. 102-114, set. 2008. Disponível em:

<https://periodicos.ufsm.br/revistadireito/article/view/7021\#.WQ3S79Ly uMq >. Acesso em: 20 fev. 2017.

AGUIAR E SILVA, Joana. Vingança e justiça na encruzilhada do direito: um patrimônio jurídico-literário. In: TRINDADE, André Karam; GUBERT, Roberta Magalhães; COPETTI NETO, Alfredo (Org.). Direito \& Literatura: reflexões teóricas. Porto Alegre: Livraria do Advogado, 2008. p. 131-145.

AZEVEDO, Bernado Montalvão Farjão de. Do assistente de acusação: o (des)assistido pela Constituição. Revista da Esmese, Aracaju, n. 12, p. 311352, 2009. Disponível em:

<http://bdjur.stj.br/dspace/handle/2011/58726>. Acesso em: 7 jan. 2017.

BARRETO, Tobias. Estudos de Fïlosofia. 2. ed. São Paulo: Grijalbo, 1977.

Disponível em:

<http://www.cdpb.org.br/estudos tobias partes 1 e 2.pdf $>$. Acesso em: 20 set 2016.

BERVEILLER, Michel. A tradição religiosa na tragédia grega. São Paulo: Companhia Editora Nacional, 1935.

BRANDÃO, Junito de Souza. Mitologia grega. Petropólis: Vozes, 1986. v. 1

BRANDÃO, Junito de Souza. Teatro grego: tragédia e comédia. Petropólis: Vozes, 1984.

COMPARATO, Fábio Konder. A afirmação histórica dos direitos humanos. São Paulo: Saraiva, 2013.

BRASIL. Superior Tribunal de Justiça. Recurso Especial n.1.451.720-SP (2014/0097833-1), publicado no DJe em 29.06.2015.

COPETTI NETO, Alfredo. Do direito na tragédia à tragédia do direito: em que perspectiva o pensamento jurídico atual compreende as ações humana? In: TRINDADE, André Karam; GUBERT, Roberta Magalhães; COPETTI NETO, Alfredo (Org). Direito \& Literatura: reflexões teóricas. Porto Alegre: Livraria do Advogado, 2008. p. 91-99.

ÉSQUILO. Oresteia: Agamenon, Coéforas, Eumênides. Rio de Janeiro: Jorge Zahar, 1991.

ÉSQUILO. Eumênides. Disponível em: <http://www.lendo.org/wpcontent/uploads/2007/06/eumenides.pdf > . Acesso em: 20 set. 2016. 
HOLMES, Oliver Wendel. $O$ direito comum: as origens do direito angloamericano. Tradução de J. L. Melo. Rio de Janeiro: Edições Cruzeiro, 1963.

KARAM, Henriete. A "Oresteia” e a origem do tribunal do júri. Revista Jurídica, Curitiba, v. 4, n. 45, p. 77-94, 2016.

https://doi.org/10.6084/m9.figshare.4622551.v1

NEVES, José Roberto de Castro. A invenção do direito: as lições de Ésquilo, Sófocles, Eurípedes e Aristófanes. Rio de Janeiro: Edições de Janeiro, 2015 .

PINTO, Cristiano Otávio Paixão Araújo. O teatro e a história do direito: a experiência da tragédia grega. In: TRINDADE, André Karam; GUBERT, Roberta Magalhães; COPETTI NETO, Alfredo (Org). Direito \& Literatura: reflexões teóricas. Porto Alegre: Livraria do Advogado, 2008. p. 69-89.

STRECK, Lenio Luiz. Tribunal do júri: símbolo \& rituais. Porto Alegre: Livraria do Advogado, 2011.

STRECK, Lenio Luiz. Os modelos de juiz e a literatura do positivismo jurídico. In: STRECK, Lenio Luiz; TRINDADE, André Karam (Org.). Os modelos de juiz: ensaios de direito e literatura. São Paulo: Atlas, 2015. p. 227-233.

OST, François. O tempo do direito. Bauru: EDUSC, 2005.

Idioma original: Português

Recebido: 05/03/17

Aceito: 27/03/17 